\title{
ANALYTICAL STUDY AND ANTIMICROBIAL ACTIVITY OF ALPHA-DEFENSIN 2 DISSOLVED IN PHARMACOPOEIA BUFFERS WITH DIFFERENT $\mathrm{pH}$
}

\author{
MAYA MARGARITOVA ZAHARIEVA', MERI NASKOVA AMERIKOVA*, \\ LILY ANTONOVA ANDONOVA², IVANKA PETKOVA PENCHEVA-EL TIBI ${ }^{2}$, \\ VANIA NIKOLOVA MASLARSKA ${ }^{3}$ and HRISTO MILADINOV NAJDENSKI ${ }^{1}$
}

${ }^{1}$ Department of Infectious Microbiology, Bulgarian Academy of Sciences, The Stephan Angeloff Institute of Microbiology, 26 Akad. G. Bonchev St., 1113 Sofia, Bulgaria

${ }^{2}$ Department of Pharmaceutical Chemistry, Faculty of Pharmacy, Medical University - Sofia, 2 Dunav St., Sofia 1000, Bulgaria

${ }^{3}$ Department of Chemistry, Faculty of Pharmacy, Medical University - Sofia, 2 Dunav St., Sofia 1000, Bulgaria

\begin{abstract}
Human neutrophil peptides (HNPs, alpha-defensins) are a group of six defensins being considered as new antimicrobial drugs because of their multifunctional efficiency against bacteria, viruses and fungi. Regardless of the unique biological properties, alpha-defensins are unstable compounds and their activity depends on many physical and chemical factors as well as on the kind of the used cultivation media. This leads to research difficulties and obstructions in their therapeutic application. The purpose of this study was to determine the antibacterial activity of alpha-defensin 2 dissolved in pharmacopeia buffers and in parallel to develop selective and accurate analytical tests for identification and assay of alpha-defensin 2 in the course of study. The antibacterial effect of alpha-defensin 2 was determined against the strain Escherichia coli (ATCC 25922). It was found that $10 \mathrm{mg} / \mathrm{L}$ of Human neutrophil peptide-2 (HNP-2, alpha-defensin 2) dissolved in $\mathrm{pH} 9.0$ buffer caused $90 \%$ inhibition of the bacterial respiratory activity. This buffer was considered as a suitable environment for deploying the antibacterial activity of the alpha-defensin. A selective MS analysis method for the identification of alpha-defensin 2 in sample mixtures was developed. Also, the HPLC method with alternative selectivity was elaborated for identification and assay of mixtures containing alpha-defensin 2 and aminoacids in Mueller Hinton broth. The procedure includes development of system suitability test determination.
\end{abstract}

Keywords: pH, antimicrobial activity, analytical study, alpha-defensin 2, buffers

Human neutrophil peptides (HNPs, alpha-defensins) are a group of six defensins being considered as new antimicrobial drugs because of their multifunctional efficiency against bacteria, viruses and fungi. Regardless of the unique biological properties, alphadefensins are unstable compounds and their activity depends on many physical and chemical factors as well as on the kind of the used cultivation media. This leads to research difficulties and obstructions in their therapeutic application. The purpose of this study was to determine antibacterial activity of alpha-defensin 2 dissolved in pharmacopeia buffers and in parallel to develop selective and accurate analytical tests for identification and assay of alpha-defensin 2 in the course of study.
The antibacterial effect of alpha-defensin 2 was determined against the strain Escherichia coli (ATCC 25922). It was found that $10 \mathrm{mg} / \mathrm{L}$ of Human neutrophil peptide-2 (HNP-2, alpha-defensin 2) dissolved in $\mathrm{pH} 9.0$ buffer caused $90 \%$ inhibition of the bacterial respiratory activity. This buffer was considered as a suitable environment for deploying the antibacterial activity of the alpha-defensin. A selective MS analysis method for the identification of alpha-defensin 2 in sample mixtures was developed. Also, the HPLC method with alternative selectivity was elaborated for identification and assay of mixtures containing alpha-defensin 2 and aminoacids in Mueller Hinton broth. The procedure includes development of system suitability test determination.

\footnotetext{
* Corresponding author: e-mail: meryamerikova@abv.bg
} 
HNPs are a group of six defensins, representing antimicrobial peptides (AMPs) with cationic moiety. They include in their molecules from 29 to 35 amino acids and three disulfide bonds between Cys1-Cys6, Cys2-Cys4, and Cys3-Cys5 residues in the secondary structure (1-3). Multifunctional efficiency against bacteria, viruses and fungi determines them as new antimicrobial drugs compared with antibiotics with large growing bacterial resistance $(4,5)$. HNP-2 is secreted in mucosal surface including eye in concentration between $0.2 \mu \mathrm{g} / \mathrm{mL}$ and $1.0 \mu \mathrm{g} / \mathrm{mL}$ (6). The mechanism of action is based on destroying the cell membrane by "carpet" and "barrel stave" models and also on targeting some intracellular structures (7). For HNP-2 there was reported antimicrobial activity against Staphylococcus aureus, Pseudomonas aeruginosa, Escherichia coli, Enterobacter aerogenes, Bacillus cereus, Mycobacterium avium and $M$. intracellulare $(8,9)$. HNP-2 is effective in vitro against M. aviumintracellulare (10). Antiviral activity of HNP-2 is studied against HIV-1, HSV-1/HSV-2, IAV, AAV, and HPV. The mechanism of antiviral activity involved blocking of the receptor binding, receptor down-modulation, extracellular aggregation, block fusion and cell signaling modulation $(11,12)$. Other function of HNPs includes chemo attractions for different types of immune cells including monocytes, CD4+ T-cells. The expression of HNPs is a mark of cancer progression and metastatic dissemination. High levels of HNPs are reported in patients with Crohn's disease, ulcerative colitis, Wegener's granulomatosis or lupus nephritis (13-15). In serum and cerebrospinal fluids of patients with Alzheimer disease are found high levels of HNP1-2 and hBD-2 human beta-defensin-2 (hBD-2) (16).

Regardless of the unique biological properties, alpha-defensins are unstable compounds and the evaluation of their antibacterial activity depends on many physical and chemical factors as well as on the kind of the $\mathrm{pH}$ and culture media used. This leads not only to research difficulties but also to obstructions of their application in the medicinal practice. Therefore, the purpose of this study was to determine the antibacterial activity of alpha-defensin 2 in buffered media and in parallel to develop selective and accurate analytical tests for identification and assay in the course of the study.

\section{EXPERIMENTAL}

\section{Reagents}

Acetonitrile HPLC grade, methanol HPLC grade, deionized water (DI), glutamic acid RS,
L-arginine aspartate $\mathrm{RS}$, buffer solutions with $\mathrm{pH}=$ 2.0, 4.0, 7.4 and $9.0 \mathrm{pH}$ units prepared according to Eur. Ph. 9, culture medium Brain Heart Infusion Broth (BHI, \#M210, HiMedia, India, ingredients: calf brain infusion, beef heart infusion, proteose peptone, dextrose, sodium chloride, disodium phosphate with final $\mathrm{pH}=7.4 \pm 0.2)$, culture medium Mueller Hinton Broth (MHB, \#M0405B, Thermo Scientific-Oxoid, UK, ingredients: beef infusion, casein acid hydrolysate, starch with final $\mathrm{pH}=7.3 \pm$ 0.1 , lyophilized amorphous powder of Human Neutrophil Peptide-2 alpha-defensin 2 (M.W. 3371.0, $\mathrm{C}_{147} \mathrm{H}_{217} \mathrm{~N}_{43} \mathrm{O}_{37} \mathrm{~S}_{6}$ ), Peptide Institute, Japan, provided by Pepta Nova GmBH.

\section{MS analysis of HNP-2 \\ Instruments}

Mass analysis was performed by using Waters Micromass ZQ, Waters Reagent Manager pump with flow rate $20 \mu \mathrm{L} / \mathrm{min}$ of rate solution from Methanol - Water $(70: 30 \mathrm{v} / \mathrm{v})$ throughout the system. Used gas is $\mathrm{N}_{2}$ with debit $150 \mu \mathrm{L} / \mathrm{min}$. Temperature of the instrument's analyzer is $120^{\circ} \mathrm{C}$ and the temperature of ionization camera $-250^{\circ} \mathrm{C}$.

\section{Preparation of stock solutions}

The stock solution of alpha-defensin 2 was prepared by dissolving $0.12 \mathrm{mg}$ lyophilized amorphous powder in DI water to obtain a solution with a concentration of $240 \mathrm{mg} / \mathrm{L}$

\section{Preparation of test solution for mass analysis}

$25 \mu \mathrm{L}$ stock solution of alpha-defensin 2 was diluted to $250 \mu \mathrm{L}$ with borate buffer $(\mathrm{pH}=9.0)$.

\section{Preparation of solution for additional ionization}

The solution for additional ionization was prepared by mixing $0.1 \%$ solution of formic acid in water and $0.1 \%$ solution of formic acid in methanol in ratio $30: 70 \mathrm{v} / \mathrm{v}$. The measured $\mathrm{pH}$ for the first solution was $2.60 \mathrm{pH}$ units and for the second $-3.60 \mathrm{pH}$ units.

HPLC determination of alpha-defensin 2 - model mixture with glutamic acid and L-arginine aspartate

\section{Instruments}

HPLC analysis was performed by isocratic elution with a flow rate of $1.0 \mathrm{~mL} / \mathrm{min}$. A high performance liquid chromatographic system (SHIMADZU Corporation, LC-20 AD quaternary pump), Shimadzu DGU-20A5 vacuum degasser and a Shimadzu SPD-20A UV/VIS detector were used for analysis. The data were recorded using Lab Solutions 
Software. The separation was carried out at $25^{\circ} \mathrm{C}$, using column Unisol, Adela Technologies, C18 ODS, $250 \times 4.6,100 \mathrm{~A}, 5 \mu \mathrm{m}$ with mobile phase - acetonitrile : DI water $-50: 50 \mathrm{v} / \mathrm{v}$, previously filtered and degassed. The analytical wavelength was $210 \mathrm{~nm}$.

\section{Preparation of solutions \\ Preparation of stock solution of alpha-defensin 2}

$0.12 \mathrm{mg}$ lyophilized amorphous powder of alpha-defensin 2 was dissolved in DI water to obtain solution with a concentration of $240 \mathrm{mg} / \mathrm{L}$.

\section{Preparation of stock solution of glutamic acid}

$10.0 \mathrm{mg}$ cristal form of glutamic acid was dissolved in DI water to obtain solution with a concentration of $0.1 \mathrm{mg} / \mathrm{mL}$.

\section{Preparation of stock solution of L-arginine aspar- tate}

$10.0 \mathrm{mg}$ L-arginine aspartate was dissolved in DI water to obtain solution with a concentration of $0.1 \mathrm{mg} / \mathrm{mL}$.

\section{Preparation of mixture of glutamic acid and L-arginine aspartate}

$1.0 \mathrm{~mL}$ stock solution of glutamic acid was diluted with $1 \mathrm{~mL}$ DI water and mixed with $2.0 \mathrm{~mL}$ stock solution of L-arginine. $20 \mu \mathrm{L}$ of the obtained mixture was injected in the HPLC apparatus.

Preparation of mixture of glutamic acid, L-arginine aspartate and alpha-defensin 2

The test solution of alpha-defensin-2 was prepared by diluting $50 \mu \mathrm{L}$ stock solution of alphadefensin 2 to $1.0 \mathrm{~mL}$ with DI water. $0.5 \mathrm{~mL}$ stock solution of glutamic acid was diluted to $1.0 \mathrm{~mL}$ with DI water and mixed with $1.0 \mathrm{~mL}$ stock solution of L-arginine. $1.0 \mathrm{~mL}$ of this solution was mixed with 50 $\mu \mathrm{L}$ test solution of alpha-defensin 2. $20 \mu \mathrm{L}$ of the obtained mixture was injected in the HPLC apparatus.

HPLC determination of alpha-defensin 2 in culture media

\section{Preparation of $\mathrm{BHI}$ solution}

$0.37 \mathrm{~g}$ of granulated culture medium was dissolved in $10.0 \mathrm{~mL}$ DI water and the obtained solution was filtrated through a membrane filter with pore size $0.45 \mu \mathrm{m}$. $20.0 \mu \mathrm{L}$ of this solution was injected in the chromatograph.

\section{Preparation of $\mathrm{MHB}$ solution}

$0.22 \mathrm{~g}$ granulated culture medium was dissolved in $10.0 \mathrm{~mL}$ DI water. After filtration, $0.1 \mathrm{~mL}$ of this solution was diluted to $100.0 \mathrm{~mL}$ with $\mathrm{DI}$ water. $20 \mu \mathrm{L}$ of this solution was injected in the chromatograph.

\section{Preparation of model mixture containing alpha- defensin 2 and $\mathrm{MHB}$ :}

$25 \mu \mathrm{L}$ stock solution of alpha-defensin 2 was diluted with $475 \mu \mathrm{L}$ borate buffer with $\mathrm{pH}=9.40 \mu \mathrm{L}$ of this solution was mixed with $160 \mu \mathrm{L}$ solution $1: 1000$ MHB. The chemical stability of this solution was examined by injecting in the HPLC apparatus in every 30 minutes.

\section{Bacterial strains and growth conditions}

The assayed bacterial strains included: Escherichia coli (ATCC 25922) and Staphylococcus aureus (ATCC 3865), both from the American Type Culture Collection (USA). The strains were maintained in Trypticase Soy Agar/Broth (TSA/TSB, \#M1968/\#LQ508, HiMedia, India) at $37^{\circ} \mathrm{C}$ under aerobic conditions. All experiments were performed using MHB and agar (MHA, \#CM0337B, Thermo Scientific-Oxoid, UK). Before each experiment, the bacterial strains were cultured on MHA overnight; thereafter, one colony was re-suspended in $10 \mathrm{~mL}$ MHB and incubated for other $18 \mathrm{~h}$ at $37^{\circ} \mathrm{C}$. This liquid culture served for preparation of a bacterial suspension in $0.9 \% \mathrm{NaCl}$ with cell density of $1 \times 10^{8}$ colony-forming units $(\mathrm{CFU} / \mathrm{mL})(0.5$ McFarland $)$ which was further diluted to $5 \times 10^{5} \mathrm{CFU} / \mathrm{mL}$ in the broth microdilution method.

\section{Determination of minimal inhibitory and bacteri- cidal concentrations}

The antimicrobial activity was estimated in 96well microplates by broth microdilution method test according to ISO 0776-1 : 2006 (E). The standardized bacterial inoculum was prepared as described in the previous section "Bacterial strains and growth conditions". The inoculums' turbidity was adjusted to McFarland $0.5\left(1 \times 10^{8} \mathrm{CFU} / \mathrm{mL}\right)$ after spectrophotometric determination $(\lambda=600 \mathrm{~nm})$ of the bacterial density and $50 \mu \mathrm{L}$ were re-suspended in 10 mL MHB. $50 \mu \mathrm{L}$ from this final bacterial suspension was added to each assayed sample in 96-well microtitre plates containing equivalent volume of MHB loaded with HNP-2 in serial dilution from. 10 to $0.156 \mathrm{mg} / \mathrm{L}$. Four different stock solutions of HNP-2 (buffers with $\mathrm{pH} 2.0,4.0,7.4$ or 9.0) were tested for antimicrobial activity in parallel to the buffers. Untreated samples served as the negative control, whereas the growth media was used to control the sterile conditions. The antibiotic gentamycin was applied as a positive control in serial dilution 
from $4 \mathrm{mg} / \mathrm{L}$ to $0.0031 \mathrm{mg} / \mathrm{L}$. The EUCAST clinical breakpoints ( $1 \mathrm{mg} / \mathrm{L}$ for $S$. aureus and $2 \mathrm{mg} / \mathrm{L}$ for $E$. coli) were used for the susceptibility assessment of the strains tested. The samples were incubated overnight at $37^{\circ} \mathrm{C}$. The lowest concentrations without visible growth were determined as minimal inhibitory concentrations (MICs). The experiments were performed in triplicate. The minimal bactericidal concentrations (MBCs) were determined after MIC readings of $100 \mu \mathrm{L}$ from each sample on MHA at $37^{\circ} \mathrm{C}$ overnight. MBCs were read as concentrations inhibiting the growth of bacterial colonies up to $100 \%$.

\section{Determination of bacterial redox activity}

For determination of the bacterial redox (respiratory) activity the samples used for the BMD assay were further incubated $\left(37^{\circ} \mathrm{C}\right)$ with the dye $3-(4,5-$ dimethylthiazolyl-2)-2, 5-diphenyltetrazolium bromide (MTT, \#M2128, Sigma-Aldrich) at final concentration $0.05 \mathrm{mg} / \mathrm{mL}$ for $180 \mathrm{~min}$. The resulting violet formazan crystals were dissolved by an equivalent volume of organic solvent $(5 \% \mathrm{HCOOH}$ in isopropanol) and the absorbance was measured at $550 \mathrm{~nm}$ (reference $690 \mathrm{~nm}$ ) on an ELISA reader (BioTek Elx800, USA) against a blank solution (MHB). High intensity of the color correlates to the high bacterial respiratory activity and lower antimicrobial effect of alpha-defensin 2 in various buffers. The MTT test is based on the reduction of the tetrazole3-(4,5-dimethylthia-zol-2-yl)-2,5-diphenyltetrazolium bromide (MTT) to its respective formazan. It was used in our study to evaluate quanti- tatively the population of the dead bacteria in parallel to the CFU enumeration, as far as dead bacteria are unable to reduce the MTT dye. For example, the use of MTT for testing the bactericidal activity of functionalized textiles has already been reported several times (20).

\section{RESULTS AND DISCUSSION}

HNP-2 (alpha-defensin 2) was identified in the sample mixtures using selectively MS analysis to determine mass changes in the peptide macromolecule of alpha-defensin 2 corresponding to the formation of multiple charges ions trough of protonation $(\mathrm{M}+\mathrm{zH})^{\mathrm{Z}+}$. In Figures 1, 2 and 3 were shown mass spectra of $\mathrm{M}^{4+}, \mathrm{M}^{3+}$ and $\mathrm{M}^{2+}$ ions corresponding to average molecular masses - 846.05, 1124.84, $1688.47 \mathrm{~m} / \mathrm{z}$.

The formula used for analysis is:

$$
\mathrm{M}=\mathrm{z}_{1}\left(\mathrm{~m}_{1}+\mathrm{mp}\right),
$$

where: $\mathrm{M}$ is mass of the molecular ion; $\mathrm{z}$ - number of charges; $\mathrm{mp}$ - mass of the proton; $\mathrm{m}_{1}$ - mass to charge ratio.

HPLC method with alternative selectivity was applied (17) for assay of alpha-defensin 2 in mixture with amino-acids that are part of peptide composition - glutamic acid and L-arginine aspartate in MHB. The procedure includes development of system suitability test determination. Some chromatographic parameters such as retention time, resolution, relative retention, symmetry factor, $L O D$ and $L O Q$ were appointed for optimization of conditions in respect of time. The results are shown in Table 1.

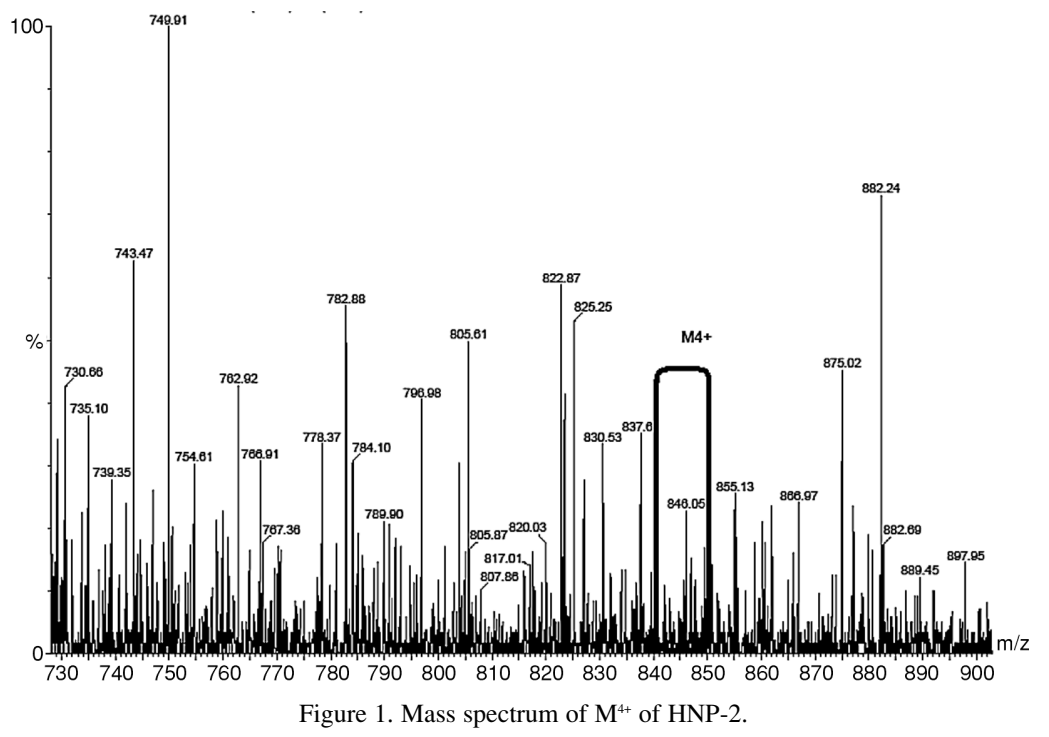



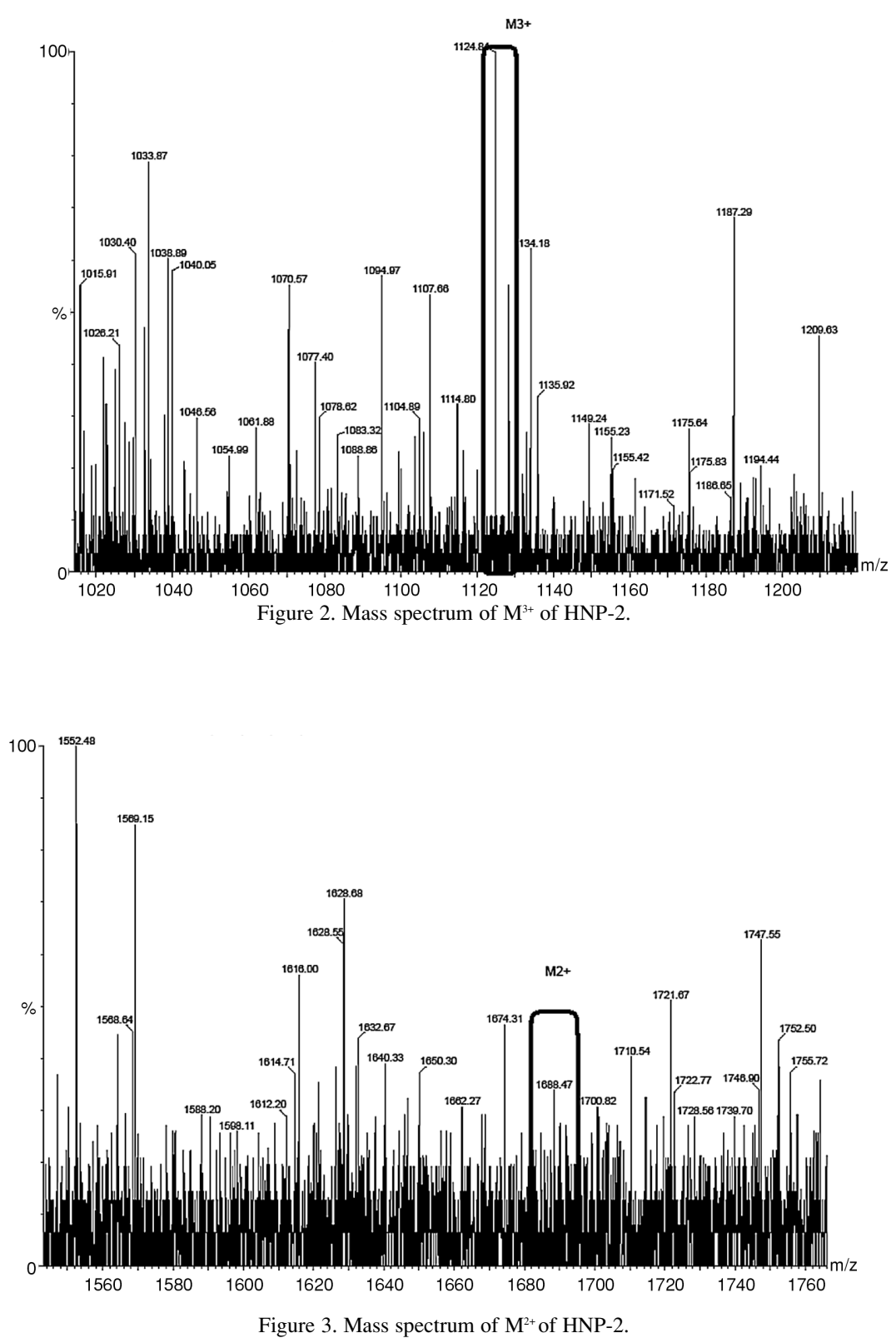

The resolution of the mixture alpha-defensin 2/amino acids in the used mobile phase acetonitrile: DI water $-50: 50 \mathrm{v} / \mathrm{v}$ (Fig. 4) is suitable for pharmacokinetic investigations and assay tests. For the time interval of $240 \mathrm{~min}$, the retention time of alpha-defensin 2 is in the method tolerance - under $\pm 2 \%$ (Table 2$)$. The peptide's chromatographic profile is not changed in the presence of culture media in a buffer solution with $\mathrm{pH}=9.0$ in contrast to solutions of different $\mathrm{pH}$, where the peptide disrupts. For identification of mixtures more acceptable is the flow rate of about 1.0 $\mathrm{mL} / \mathrm{min}$ for the used mobile phase.

\section{Antimicrobial activity of HNP-2}

The antimicrobial activity of HNP-2 was tested on one $S$. aureus strain (Gram-positive) and one E. coli strain (Gram-negative) by using four different pharmacopoeia buffers with $\mathrm{pH} 2.0,4.0,7.4$ or 9.0 for dissolving the protein. The maximal tested concentration for both strains $(10 \mathrm{mg} / \mathrm{L})$ was chosen according to previously published data $(18,19)$. HNP-2 inhibited effectively the growth of the Gramnegative strain $E$. coli at a minimal inhibitory concentration of $10 \mathrm{mg} / \mathrm{L}$ when it was dissolved in buffer with $\mathrm{pH}$ 9.0. This effect was bacteriostatic as 
far as HND-2 did not inhibit the colony formation of $E$. coli after cultivation of the treated bacteria on MHA for $24 \mathrm{~h}\left(37^{\circ} \mathrm{C}\right)$. Concentrations of HNP-2 up to $50 \mathrm{mg} / \mathrm{L}$ did not exert a bactericidal effect, as well. However, the number of colony forming units at concentration of $10 \mathrm{mg} / \mathrm{L}$ did not exceed $1 \times 10^{4}$ $\mathrm{CFU} / \mathrm{mL}$ which is by one logarithm less than the density of the initial bacterial inoculum $\left(5 \times 10^{5}\right.$ $\mathrm{CFU} / \mathrm{mL}$ ) and is an evidence for inhibition of the bacterial growth. The inhibition of MTT reduction after treatment with alpha defensin paralleled the reduction in the number of CFU. The $S$. aureus strain turned out to be not sensitive to the alphadefensin 2 exposure in all four buffers tested.

The redox activity of $E$. coli was determined after treatment with HNP-2 with the MTT-dye assay. HNP-2 dissolved in buffer with $\mathrm{pH} 9.0$ inhibited the bacterial respiratory metabolism of the $E$. coli strain up to $91.1 \pm 0.6 \%$ as visible from Figure 5 and Table 3. The effect of the buffer itself was $36.57 \pm 1.2 \%$ inhibition, i. e. with $54.5 \%$ less than that of the protein dissolved in the same buffer. In

Table 1. Chromatographic parameters from system suitability test.

\begin{tabular}{|c|c|c|c|}
\hline Parameter & Alpha - defensin 2 & Glutamic acid & L-arginine aspartate \\
\hline Retention time (min) \pm SD & $1.82 \pm 0.0194$ & $2.15 \pm 0.0180$ & $3.81 \pm 0.0745$ \\
\hline Resolution & - & 1.348 & -266 \\
\hline LOD $(\mathrm{mg} / \mathrm{mL})$ & 0.00024 & - & - \\
\hline LOQ $(\mathrm{mg} / \mathrm{mL})$ & 0.00012 & 1.281 & 2.271 \\
\hline Relative retention & - & 0.66 & 0.14 \\
\hline Symmetry factor & 1.01 & & - \\
\hline
\end{tabular}

Table 2. Content in $\%$ of alpha-defensin 2 at $\mathrm{pH}=9$ in MHB.

\begin{tabular}{|c|c|c|c|c|c|}
\hline Time $(\mathrm{min})$ & $\mathrm{t}_{\mathrm{r}}(\mathrm{min})$ & Area $(\mathrm{AU})$ & Height $(\mathrm{AU})$ & Area $(\%)$ & Height $(\%)$ \\
\hline 0 & 1.779 & 1024482 & 25394 & 98.684 & 98.690 \\
\hline 30 & 1.819 & 145512 & 7168 & 16.238 & 23.313 \\
\hline 60 & 1.847 & 84552 & 4469 & 14.778 & 18.991 \\
\hline 90 & 1.840 & 87595 & 4593 & 15.774 & 19.925 \\
\hline 120 & 1.831 & 90706 & 4819 & 16.555 & 20.751 \\
\hline 150 & 1.825 & 96166 & 5123 & 17.479 & 21.810 \\
\hline 180 & 1.844 & 62455 & 3621 & 14.506 & 19.603 \\
\hline 210 & 1.813 & 93692 & 5160 & 18.077 & 23.079 \\
\hline 240 & 1.822 & 74167 & 4270 & 16.657 & 22.111 \\
\hline
\end{tabular}

Legend: $\operatorname{tr}$ - retention time of analyte in min; Area - area under the peaks in absorption units (AU) and \% Height - height of the peaks in absorption units (AU) and \%.

Table 3. Comparison between the antibacterial effect of borate buffer with and without HNP-2 on the redox activity of Escherichia coli (ATCC 25922) after $24 \mathrm{~h}$ of exposure.

\begin{tabular}{|c|c|c|}
\hline Sample & Absorbance $(\lambda=550 \mathrm{~nm}) \pm \mathrm{SD}^{*}$ & {$[\%]$ of untreated control \pm SD } \\
\hline Control & $3.08 \pm 0.087$ & $100 \pm 9.8$ \\
\hline $\begin{array}{c}10 \mathrm{mg} / \mathrm{L} \text { HNP-2 in } 50: 50 \\
\text { buffer }(\mathrm{pH} \text { 9) and bacterial } \\
\text { suspension in MHB }\end{array}$ & $0.729 \pm 0.016$ & $8.905 \pm 0.62$ \\
\hline $50: 50$ buffer $(\mathrm{pH}$ 9) and MHB & $1.954 \pm 0.065$ & $63.43 \pm 2.1$ \\
\hline
\end{tabular}

Legend: *SD - standard deviation. 


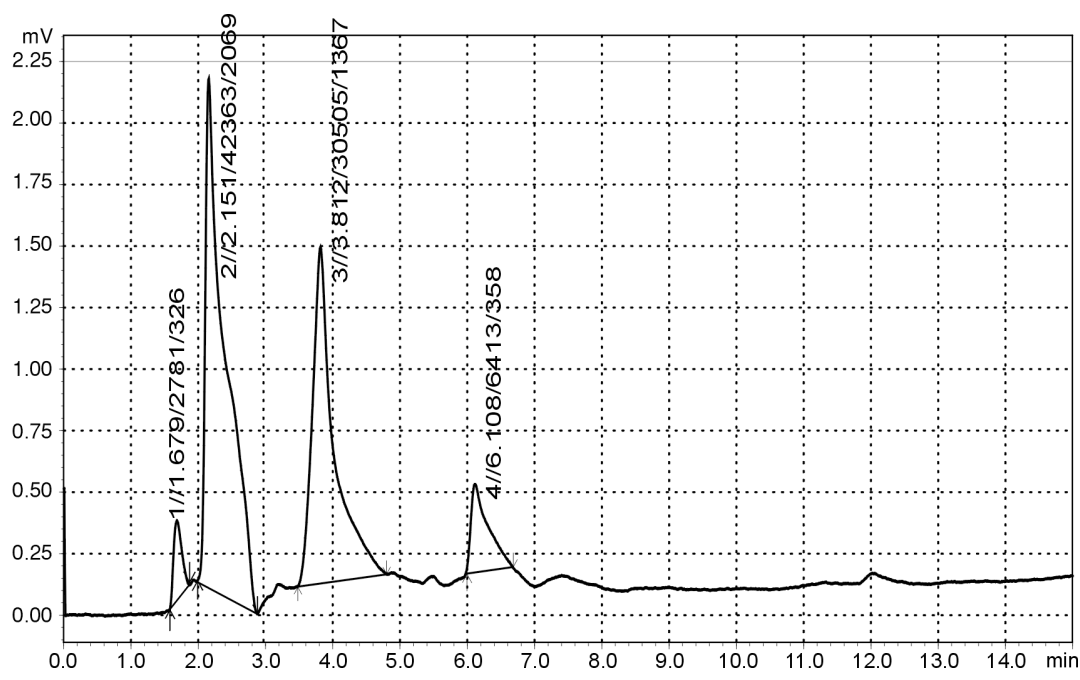

Figure 4. Chromatogram of mixture alpha-defensin 2, glutamic acid and L-arginine aspartate.

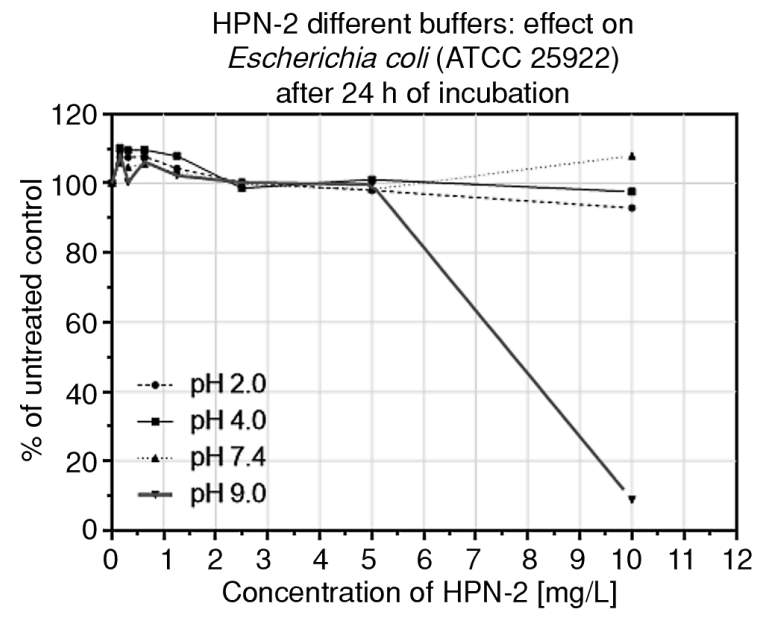

Figure 5. Effect of HNP-2 on the redox activity of Escherichia coli (ATCC 25922).

contrast, the other three buffers $(2.0,4.0$ and $7.4 \mathrm{pH})$ used for dissolving of HNP-2 did not provide a stable milieu for revealing its antibacterial properties, most probably due to the low stability of the protein. The highest activity of HNP-2 was observed at a concentration of $10 \mathrm{mg} / \mathrm{L}$, whereas all other concentrations were found to be ineffective. Our result correlated with the data published by Ericksen et al. (19) about the antibacterial effect of HNP-2 against the same strain E. coli used in our study (ATCC 25922). The authors found that HNP-2 inhibited the growth of the treated bacteria with $90 \%$ at a concentration of $8.4 \pm 1.3 \mathrm{mg} / \mathrm{L}$. This effect was calculated after measurement of the optical density of the bac- terial culture $\left(\mathrm{OD}_{650}\right)$ whereas in our experiment we used the MTT dye to determine the respiratory activity of the survived bacteria.

The effect of HNP-2 on Escherichia coli (ATCC 25922) in buffer with $\mathrm{pH} 9.0$ was compared to the effect of the buffer itself. The effect of the buffer was sevenfold weaker than this of the defensin. The results are presented in Table 3.

\section{CONCLUSION}

The antibacterial effect of alpha-defensin 2 against the Escherichia coli strain ATCC 25922 was demonstrated after stabilization of the peptide in a 
buffer with $\mathrm{pH}$ 9.0. Under these conditions, the minimal inhibitory concentration of HNP-2 was determined at $10 \mathrm{mg} / \mathrm{L}$ causing $90 \%$ inhibition of the bacterial metabolic activity. In order to determine mass changes in the peptide macromolecule, a selective MS analysis method for the identification of alphadefensin 2 in sample mixtures was developed. Also, the HPLC method with alternative selectivity was elaborated for the identification of mixtures and assay of alpha-defensin 2 in MHB. The procedure includes development of system suitability test determination.

In conclusion, the $\mathrm{pH} 9.0$ buffer efficiently stabilizes the peptide macromolecule of alpha-defensin 2 , thereby providing a suitable environment for deploying its antibacterial activity.

\section{Conflict of interest}

The authors declare no conflicts of interest.

\section{REFERENCES}

1. Patel S., Akhtar N.: Biomed. Pharmacother. 95, 1276 (2017).

2. Chung P.Y., Khanum R.: J. Microbiol. Immunol. Infect. 50, 405 (2017).

3. Jarczak J., Kościuczuk E.M., Lisowski P., Strzałkowska N., Joźwik A., et al.: Hum. Immunol. 74, 1069 (2013).

4. Cunha N.B., Cobacho N.B., Viana J.F.C., Lima L.A., Kamila B.O., et al.: Drug Discov. Today 22, 234 (2017).

5. Dawgul M., Maciejewska M., Jaskiewicz M., Karafova A., Kamysz W.: Acta Pol. Pharm. 71, 39 (2014).
6. Silva N.C., Sarmento B., Pintado M.: Int. J. Antimicrob. Agents 41, 5 (2013).

7. Frasca L., Lande R.: Curr. Pharm. Biotechno. 13, 1882 (2012).

8. Wang G.: Pharmaceuticals 7, 545 (2014).

9. Pachon-Ibanez M.E., Smani Y., Pachon J., Sanchez-Cespedes J.: FEMS Microbiol. Rev. 41, 323 (2017).

10. Dong H., Lv Y., Zhao D.,Barrow P., Zhou X.: J. Immunol. Res. 11, 1 (2016).

11. Wilson S.S.,Wiens M. E., Smith J.G.: J. Mol. Biol. 425, 4965 (2013).

12. Shartouny J.R., Jacob J.: Semin. Cell Dev. Biol. 88, 147 (2018).

13. Fruitwala S., El-Naccache D.W., Chang T.L.: Semin. Cell Dev. Biol. 88, 163 (2019).

14. Fuente-Núñez C., Silva O.N., Lu T.K., Franco O.L.: Pharmacol. Ther. 178, 132 (2017).

15. Suarez-Carmona M., Hubert P., Delvenne P., Herfs M.: Cytokine Growth Factor Rev. 26, 361 (2015).

16. Szekeres M., Ivitz E., Datki Z., Kálmán J., Pákáski M., et al.: Psychiatry Res. 239, 342 (2016).

17. Wua Z, Cocchia F, Gentlesa D, Ericksena B, Lubkowskib J., et al.: FEBS Lett. 579, 162 (2005).

18. Ericksen B., Wu Z., Lu W, Lehrer R.I.: Antimicrob. Agents Chemother. 49, 269 (2005).

19. Takemura H., Kaku M., Kohno S., Hirakata Y., Tanaka H., et al.: Antimicrob. Agents Chemother. 40, 2280 (1996).

20. Mahltig B., Darko D., Günther K., Haase H.: J. Fashion Technol. Textile Eng. 3, 1 (2015).

(c) 2020 by Polish Pharmaceutical Society. This is an open access article under the CC BY NC license (c) (1) (9) (http://creativecommons.org/licenses/BY/4.0/). 